\title{
How Sensitive Are Fault-Slip Rates in the Los Angeles Basin to Tectonic Boundary Conditions?
}

\author{
by W. Ashley Griffith* and Michele L. Cooke
}

\begin{abstract}
Geodetic studies have produced different interpretations of the relative vertical thickening versus escape tectonics occurring within the Los Angeles basin based on calculated horizontal strain rates ranging from $56 \times 10^{-9} / \mathrm{yr}$ contraction at $\mathrm{N} 36^{\circ} \mathrm{E}$ to $85 \times 10^{-9} / \mathrm{yr}$ north-south contraction and $60 \times 10^{-9} / \mathrm{yr}$ east-west extension. Three-dimensional forward mechanical models of faults in the Los Angeles basin are used to compare modeled slip rates and slip styles, represented as the rakes of average net slip vectors, under four representative horizontal strain conditions with geologically determined late-Quaternary slip rates and observed slip styles. The comparisons strive to identify the most mechanically viable tectonic boundary conditions for the Los Angeles basin. The three-dimensional fault surfaces used within the mechanical models have been defined by Southern California Earthquake Center (SCEC) workers based on surface geology and subsurface data. The model results suggest that northeast-southwest principal contraction is inappropriate for the Los Angeles basin because this tectonic boundary condition produces left-lateral slip along the Whittier and San Gabriel faults in contrast with abundant geologic evidence of right-lateral slip. Of the four tectonic boundary conditions evaluated, north-south contraction accompanied by either zero or slow east-west contraction gives the lowest mismatch of modeled and observed fault slip style. These results suggest that vertical thickening may be more predominant than escape tectonics in this region.
\end{abstract}

\section{Introduction}

The Los Angeles basin has been shaped by a variety of tectonic regimes during the past 18 m.y., including Miocene transtension and present-day transpression (e.g., Ingersoll and Rumelhart, 1999; Nicholson et al., 1994; Wright, 1991). Geodetic investigations within the Los Angeles basin estimate present-day north-south (Feigl et al., 1993; Walls et al., 1998; Argus et al., 1999) to northeast-southwest contraction (Bawden et al., 2001). This strain is accommodated along active systems of east-west oriented reverse-slip faults and southwest-northeast and northwest-southeast striking strike-slip faults (e.g., Walls et al., 1998). The concurrence of both reverse- and strike-slip faulting is in part due to the multistage evolution of the basin. For example, many strikeslip faults, such as the Whittier fault, formed as normal faults under earlier transtension and were later reactivated as strike-slip faults under transpression (e.g., Ingersoll and Rumelhart, 1999; Dolan et al., 2001). The direction and magnitude of present-day tectonic strains may favor slip on one

*Present address: Department of Geological and Environmental Sciences, Stanford University, Stanford, California 94305. wagrif@ pangea.stanford.edu fault system over another so that the tectonic boundary conditions control the slip rates and associated seismic hazard of these systems of reverse-slip and strike-slip faults.

Different sources of Global Positioning System (GPS) data (i.e., campaign versus permanent) and different methods of data analysis can lead to a variety of present-day surface velocity estimates for the same region. Several geodetic studies estimate nearly north-south and east-west principal strain for the Los Angeles basin but with differing amounts of east-west strain (Walls et al., 1998; Argus et al., 1999). These studies demonstrate north-south shortening accompanied by either east-west $60 \times 10^{-9} / \mathrm{yr}$ extension (Walls et al., 1998) or approximately zero east-west extension (Fig. 1a,b) (Argus et al., 1999). The difference between these east-west rates may be expressed as different patterns of strain partitioning among fault sets. In the absence of east-west lengthening, north-south shortening may be accommodated by vertical thickening of the crust (Argus et al., 1999), primarily via slip along blind-thrust faults. In contrast, the "escape tectonics" hypothesis of Walls et al. (1998) posits that east-west extension in conjunction with northsouth contraction promotes right-lateral strike slip along northwest-southeast striking faults. Both styles of faulting 
A) B)

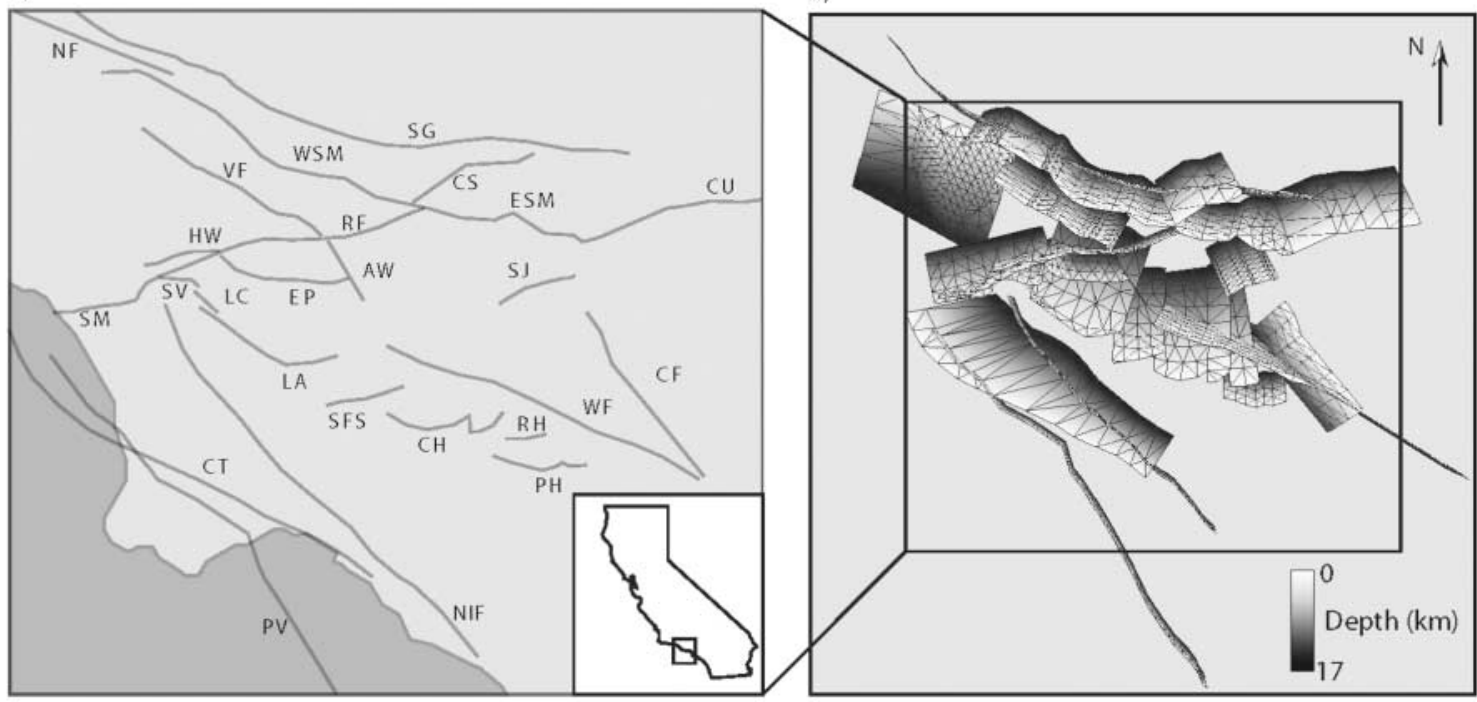

Figure 1. (a) Map of the Los Angeles basin with traces of upper tip lines of modeled faults projected to the surface. Modeled faults include the West Sierra Madre (WSM), East Sierra Madre (ESM), Verdugo (VF), San Gabriel (SG), Clamshell-Sawpit (CS), Cucamonga (CU), San Jose (SJ), Northridge (NF), Los Angeles (LA), Santa Fe Springs (SFS), Coyote Hills (CH), Whittier (WF), Santa Monica (SM), Hollywood (HW), Raymond (RF), San Vicente (SV), Las Cienagas (LC), Alhambra Wash (AW), Richfield $(\mathrm{RH})$, Peralta Hills (PH), Chino (CF), Compton (CT), Newport-Inglewood (NIF), Redondo Canyon (RCF), and Palos Verdes (PV) faults. (b) Map view projection of threedimensional geometry of modeled faults. Faults are shaded by depth, and the triangular mesh of each fault is shown. By utilizing triangular elements, nonplanar faults can be accurately represented.

are found within the basin, but the two models predict differing degrees of activity along strike-slip and reverse faults.

Furthermore, a recent geodetic study that considers the contribution of groundwater withdrawal to measured surface deformation estimates principal contraction of $56 \times 10^{-9} /$ yr at $\mathrm{N} 36^{\circ} \mathrm{E}$ (Bawden et al., 2001). To place this measurement within the spectrum of vertical thickening to escape tectonics, the $\mathrm{N} 36^{\circ} \mathrm{E}$ contraction can be resolved into northsouth and east-west contraction, which promotes greater crustal thickening than the Argus-type model as well as a horizontal component of pure shear. Thus, the three geodetic studies range from greatest crustal thickening with $56 \times$ $10^{-9} / \mathrm{yr}$ contraction at $\mathrm{N} 36^{\circ} \mathrm{E}$ to escape tectonics under 85 $\times 10^{-9} / \mathrm{yr}$ north-south contraction with $60 \times 10^{-9} / \mathrm{yr}$ eastwest extension.

Validating the most appropriate tectonic boundary conditions for the Los Angeles basin requires comparison of tectonic strains to additional data sets such as fault-slip rates (e.g., Walls et al., 1998). However, such validation of regional strain estimates is complicated by the uncertain relationship between geologically determined slip rates on known faults and horizontal surface velocities observed during the past decade by GPS. Walls et al. (1998) attempt to bridge the gap between geologic and geodetic observations by adjusting slip rates on faults to match geodetic observa- tions of active strain. Although this approach yields interesting insights for the relative seismic hazard of known faults, problems arise because the method assumes rigid material between fault surfaces, and the method ignores nonuniform slip on interacting faults.

This study utilizes three-dimensional continuum mechanics-based models to compare fault slip rates and slip vector rakes resulting from a variety of proposed tectonic boundary conditions acting in the Los Angeles basin. The boundary element method (BEM) code Poly3D incorporates frictionless, nonplanar, three-dimensional fault surfaces defined by the Southern California Earthquake Center (SCEC) Community Fault Model (CFM) workers (e.g., Plesch and Shaw, 2000). The CFM faults are defined to a depth of about $17 \mathrm{~km}$ (Fig. 1b) and, in general, are not linked at depth by master detachments such as those described by Fuis et al. (2001, 2003). Within our models, these fault surfaces accommodate slip and interact in response to remote strain conditions that simulate variable degrees of vertical thickening and escape tectonics. These forward models allow elastic deformation around faults and nonuniform slip along interacting faults. Models with slip rates and styles that match geologic observations may more accurately simulate regional deformation than models with significant mismatch. Although mismatch of individual fault-slip rates may stem from incorrect fault geometry or missing nearby faults, we 
assess the regional tectonic boundary conditions by considering the overall mismatch of all faults.

\section{Geologic Fault Slip Rates and Tectonic Setting}

The Los Angeles basin contains primarily three fault orientations: east-west striking reverse, northeast-southwest striking oblique and strike slip, and northwest-southeast striking oblique and strike slip (Fig. 1). Geologic slip rates used in this study are summarized in Table 1.

\section{Slip Rates on Faults of the Los Angeles Basin}

Reverse faults examined in the northern basin include the West Sierra Madre, East Sierra Madre, Cucamonga, Clamshell-Sawpit, Northridge, San Jose, and Verdugo faults (Fig. 1). The Sierra Madre fault extends for $75 \mathrm{~km}$ at the base of the San Gabriel Mountains (Crook et al., 1987), and, in keeping with Dolan et al. (2001), is divided into the West and East Sierra Madre faults at the intersection of this fault with the Clamshell-Sawpit and Raymond faults. The trace orientation of the West Sierra Madre fault varies, in general, striking east-west and dipping to the north. Rubin et al. (1998) determined that the West Sierra Madre fault has ruptured in at least two events in the past $18 \mathrm{ka}$, leading to a minimum slip rate of $0.6 \mathrm{~mm} / \mathrm{yr}$. The East Sierra Madre fault merges along a left-lateral fault with the Cucamonga fault to the east. Tucker and Dolan (2001) determined a minimum slip rate of $0.9 \mathrm{~mm} / \mathrm{yr}$ for the East Sierra Madre fault between 24 and $8 \mathrm{ka}$ and $0.6 \mathrm{~mm} / \mathrm{yr}$ before $24 \mathrm{ka}$. Geomorphic expression of the Cucamonga fault, an east-west striking, north-dipping reverse fault indicates slip rates between 2 and $5 \mathrm{~mm} / \mathrm{yr}$, higher than that of the adjacent East Sierra Madre fault (Crook et al., 1987). The southeast-striking and northdipping Verdugo fault is south of and strikes subparallel to the West Sierra Madre fault (Tsutsumi and Yeats, 1999; Langenheim et al., 2000). The Northridge fault, a south-dipping blind-thrust fault, remained unrecognized until the 1994 Northridge earthquake. The preferred long-term slip rate from stratigraphic thickness changes in thickness of the Saugus Formation is between 1.4 and $1.7 \mathrm{~mm} / \mathrm{yr}$ (Davis and Namson, 1994; Huftile and Yeats, 1996). The San Jose fault lies at the base of the southern San Jose Hills front and dips to the north, although slip rate is poorly constrained (Dolan et al., 2001).

In the eastern Los Angeles basin, the Puente Hills blindthrust system (PHT), believed to be the source of the 1987 Whittier Narrows earthquake, is divided into three echelon segments underlying downtown Los Angeles: the Los Angeles, Santa Fe Springs, and Coyote Hills thrusts (Shaw and Shearer, 1999, Shaw et al., 2002). The kinematically inferred slip rate on these faults varies from 0.44 to $1.70 \mathrm{~mm} /$ yr (Shaw et al., 2002). Models by Griffith and Cooke (2004) suggest that the PHT intersects and offsets the Whittier fault along the Coyote Hills segment and significant strike slip may accompany reverse slip along these structures. Schnei-
Table 1

Published Geologic Slip Rates for Los Angeles Basin Faults

\begin{tabular}{|c|c|c|c|c|}
\hline Fault & $\begin{array}{l}\text { Reverse-Slip Rate } \\
(\mathrm{mm} / \mathrm{yr})\end{array}$ & Ref.* & $\begin{array}{l}\text { Strike-Slip Rate } \\
\quad(\mathrm{mm} / \mathrm{yr})\end{array}$ & Ref.* \\
\hline Santa Fe Springs & $0.4-0.82$ & 19 & & \\
\hline Los Angeles & $0.60-1.13$ & 19 & & \\
\hline Coyote Hills & $0.90-1.70$ & 19 & & \\
\hline Palos Verdes & 0.38 & 15 & $2.5-3.5$ & 15 \\
\hline Santa Monica & $\begin{array}{c}1.0 \pm 0.5 \\
\text { (lower range preferred) }\end{array}$ & 5 & $<0.5$ & 17 \\
\hline Northridge & $\begin{array}{c}1.5 \pm 0.5 \\
(1.7 \text { preferred })\end{array}$ & 3,10 & & \\
\hline Cucamonga & $2.0-5.0$ & 11,16 & & \\
\hline San Gabriel & & & $1.0-2.5$ & 12,22 \\
\hline West Sierra Madre & $0.6-2.2$ & 2,18 & & \\
\hline East Sierra Madre & $>0.6$ & 21 & & \\
\hline Whittier & $0.3-0.9$ & 1 & $1.0-3.0$ & 7 \\
\hline Hollywood & & & $>0.25$ & 4 \\
\hline Raymond & & & $1.5 \pm 0.5$ & 14 \\
\hline Clamshell-Sawpit & $0.5 \pm 0.5$ & 2,9 & & \\
\hline Verdugo & $0.5 \pm 0.5$ & 4 & & \\
\hline Newport-Inglewood & & & $0.3-1.5$ & $6,8,13$ \\
\hline Compton & $1.5 \pm 0.5$ & 20 & & \\
\hline Chino & & & $1.0 \pm 1.0$ & 17 \\
\hline
\end{tabular}

*References: (1) Bjorklund, personal comm., 2003; (2) Crook et al. (1987); (3) Davis and Namson (1994); (4) Dolan and Pratt (1997), Dolan et al. 2000b; (5) Dolan et al. (2000a); (6) Freeman et al. (1992), (7) Gath et al. (1992); (8) Grant et al. (1997); (9) Hauksson (1994); (10) Huftile and Yeats (1996); (11) Jones et al. (1990); (12) Kahle (1986); (13) Lindvall et al. (1995); (14) Marin et al. (2000); (15) McNeilan et al. (1996); (16) Petersen and Wesnouski (1994); (17) Dolan and Pratt, (1997); (18) Rubin et al. (1998); (19) Shaw et al. (2002); (20) Shaw and Suppe (1996); (21) Tucker and Dolan (2001); (22) Yeats and Huftile (1994).

der et al. (1996) model the Las Cienagas fault as a northdipping blind thrust with late-Quaternary slip rate between 1.1 and $1.5 \mathrm{~mm} / \mathrm{yr}$; however, the slip rate for the past 330 $\mathrm{ka}$ has been estimated from vertical displacement at about an order of magnitude less (Ponti et al., 1996; Quinn et al., 2000). The Upper Elysian Park fault, a north-dipping thrust fault northeast of the Las Cienagas fault, lies in the hanging wall of the Los Angeles segment of the PHT and has produced uplift of the Elysian, Repetto, and Monterey Park Hills (Dolan et al., 2001). Oskin et al. (2000) estimated a late-Quaternary slip rate of $0.8-2.2 \mathrm{~mm} / \mathrm{yr}$ based on parasitic minor folds across the Coyote pass escarpment, with fault dip inferred from analysis of growth strata. Davis et al. (1989) and Shaw and Suppe (1996) interpret up to $4 \mathrm{~km}$ of slip on the Compton fault based on growth strata. Long-term reverse-slip rate is inferred as $1.4 \pm 0.4 \mathrm{~mm} / \mathrm{yr}$ (Shaw and Suppe, 1996), although slip rate in its current, shallowly dipping orientation has been modeled as far less (Cooke and Kameda, 2002). The Peralta Hills fault is a poorly constrained north-dipping thrust structure that lies south of the Coyote folds (Dolan et al., 2001). The lower Elysian Park fault, a thrust ramp below the Puente Hills fault, is not included in our model as it is omitted as a major active fault in Dolan et al. (2001).

Oblique-slip faults include the Santa Monica, Holly- 
wood, Raymond, San Gabriel, Whittier, Palos Verdes, and Chino faults (Fig. 1). The Santa Monica fault, part of the Transverse Ranges Southern Boundary fault system (TRSB), has surface expression in the form of a series of left-stepping echelon, south-facing scarps. Reverse-slip rate of the Santa Monica fault has been estimated at $\sim 0.5-0.6$ $\mathrm{mm} / \mathrm{yr}$ from offset of marine terraces, although direct evidence of strike-slip rate has not been established (McGill, 1989; Dolan and Pratt, 1997; Dolan et al., 2000a, 2001). The Santa Monica mountains have been uplifted over the past several years along the Santa Monica blind thrust $(0.5 \pm$ $0.4 \mathrm{~mm} / \mathrm{yr}$ ), which may merge with the Santa Monica fault (Meigs et al., 1999). The Hollywood fault, also part of the TRSB, trends east-northeast for a distance of $14 \mathrm{~km}$, intersecting the Santa Monica fault to the west, and merging with the Raymond fault to the east (Dolan et al., 2000a). Within the last $9 \mathrm{ka}$, the reverse-separation rate along the Hollywood fault has been slow; however, Dolan and Pratt (1997) estimate the strike-separation rate at greater than $0.25 \mathrm{~mm} / \mathrm{yr}$. The Raymond fault trends east-northeast forming the eastern extent of the TRSB and has a large left-lateral slip component and minor reverse-separation component (Crook et al., 1987; Jones et al., 1990; Dolan et al., 2000a). The San Gabriel fault cuts across the Transverse Ranges as a remnant of the San Andreas system. Slip on this fault slowed in the Pliocene and varies along strike from right-lateral to reverse (e.g., Yeats and Huftile, 1994). Long-term slip rate has been estimated at $\sim 1 \mathrm{~mm} / \mathrm{yr}$ (Kahle, 1986) to $2.5-3 \mathrm{~mm} / \mathrm{yr}$ (Yeats and Huftile, 1994), although late-Quaternary rates could be smaller (Dolan et al., 2001). The Whittier fault strikes roughly west-northwest and curves to the east to a northwestern orientation merging with the Elsinore fault. Slip rate on the Whittier fault is highly debated, as is the predominant slip style. Gath et al. (1992) estimated a right-lateral slip rate of 1-3 mm/yr based on offset terraces of the Santa Ana river; however, strike-slip rate on the Whittier fault is difficult to interpret because of significant reverse slip on the western and central portions of the fault (Bjorklund and Burke, 2002). Estimates of reverse-slip rate on the central portion of the Whittier fault during the past 1 Ma range from 0.3 to $0.9 \mathrm{~mm} / \mathrm{yr}$ (T. Bjorklund, personal comm., 2003). The Chino fault is a right-lateral member of the Elsinore fault system with consistent reverse separation (Gray, 1961; Durham and Yerkes, 1964; Schoellhammer et al., 1981; Rockwell et al., 1992). This fault is believed to be active although slip rate is poorly constrained.

In the western Los Angeles basin, the Palos Verdes fault lies at the northeastern range front of the Palos Verde Hills extending onto the continental shelf to the southeast (Dolan et al., 2001) and ending in a series of reverse splays, including the Redondo Canyon fault to the north (Nardin and Henyey, 1978). McNeilan et al. (1996) determined a minimum Holocene reverse-slip rate of $0.38 \mathrm{~mm} / \mathrm{yr}$ and strikeslip rate of $2.5-3.5 \mathrm{~mm} / \mathrm{yr}$ from direct geophysical observations. Modeled reverse-slip rates for the Palos Verdes fault range from $0.4 \mathrm{~mm} / \mathrm{yr}$ (Cooke and Kameda, 2002) to $1.2 \pm$ $0.4 \mathrm{~mm} / \mathrm{yr}$ (Shaw and Suppe, 1996).

Predominantly strike-slip faults in the basin include the Newport-Inglewood and Alhambra Wash faults (Fig. 1). The Newport-Inglewood fault zone consists of a series of uplifts and anticlines and has been marked by diffuse historical seismicity, including the 1933 Long Beach earthquake (Hauksson, 1987; 1990). Holocene strike-slip rate is estimated at 0.30-0.55 mm/yr near the Huntington Beach oil field (Grant et al., 1997); however, some reverse slip and related uplift has been observed along restraining bends (Tsutsumi et al., 2001). Trenches along the Alhambra Wash fault, a northern splay of the Whittier fault show right-lateral strike-slip rate of $0.2 \pm 0.1 \mathrm{~mm} / \mathrm{yr}$ (Gath et al., 1992).

\section{Tectonic Setting: Vertical Thickening}

versus Escape Tectonics

Geodetic estimates of north-south shortening rate across the Los Angeles basin range from $\sim 30 \times 10^{-9} / \mathrm{yr}$ (Bawden et al., 2001) to $\sim 60 \times 10^{-9} / \mathrm{yr}$ (Feigl et al., 1993; Argus et al., 1999) to $\sim 85 \times 10^{-9} / \mathrm{yr}$ (Walls et al., 1998) to $\sim 100 \times 10^{-9} / \mathrm{yr}$ (Argus et al., 1999). East-west components of deformation have an even greater range, from $\sim 20 \times 10^{-9} / \mathrm{yr}$ contraction (Bawden et al., 2001) to zero (Argus et al., 1999) to $\sim 60 \times 10^{-9} / \mathrm{yr}$ extension (Walls et al., 1998). The range of rates arises from considerations of different contributions to error in the GPS signal. Deformation rates of Argus et al. (1999) differ from Walls et al. (1998) primarily because of the removal of strain induced by motion of the San Andreas Fault. The estimates of Bawden et al. (2001) remove effects of ground-water withdrawal and slip along the Palos Verdes, Newport-Inglewood, or Whittier faults, resulting in principal strain axes between $30^{\circ}$ and $36^{\circ}$ east of the other geodetic estimates. Although this principal contraction direction may not be representative of the region because strike slip was removed along these faults, inclusion of this contraction direction in our systematic study of tectonic boundary conditions illustrates the sensitivity of fault-slip rates and slip styles to oblique contraction. The differences in resolved east-west strain rates may have significant implications for faulting: east-west extension implies escape tectonics, facilitated predominantly by northeast-southwest and northwest-southeast trending strikeslip faults. In contrast, east-west contraction rates imply significant vertical thickening of the basin via thrust and oblique-slip faults. Both camps may be partially correct in that east-west extension due to motion on northeast-southwest and northwest-southeast trending strike-slip faults can certainly be accompanied by reverse-slip on east-west striking thrust faults.

\section{Model Setup}

Deformation in the Los Angeles basin is simulated using Poly3D, a three-dimensional boundary element method 
(BEM) code that calculates the deformation of a faulted, but otherwise homogeneous and isotropic linear-elastic, semiinfinite half-space (Thomas, 1993). Poly3D numerically solves the governing differential equations of continuum mechanics (Crouch and Starfield, 1990). Poly3D can simulate the deformation of any homogeneous and isotropic three-dimensional body if either the tractions or displacements are prescribed on the surfaces of that body. Thus, the stress and strain fields throughout the body are uniquely determined by the prescribed boundary conditions (i.e., remote strain and fault tractions). Within the models of this study, remote horizontal strain drives slip along frictionless fault surfaces that are neither allowed to open nor interpenetrate. The three-dimensional faults are discretized into two-dimensional polygons each of which has constant slip and opening (Thomas, 1993). Triangular elements provide accurate simulation of nonplanar fault surfaces (Fig. 1). As a BEM code, Poly3D only requires discretization of the faults, rather than volumetric meshing of surrounding rock required by the finite element method. Consequently, this code facilitates easy manipulation of fault geometry (e.g., Thomas, 1993; Crider, 1998; Savage, 2003; Savage and Cooke, 2003; Griffith and Cooke, 2004).

\section{Tectonic Boundary Conditions}

We apply four representative combinations of remote strain rates to the Los Angeles basin fault model to assess the sensitivity of fault-slip rates and slip style to tectonic boundary conditions (Fig. 2). These tectonic boundary conditions arise from differing assumptions made in processing the GPS data (i.e., removal of the San Andreas signature, removal of groundwater pumping effects, etc.). Because the geodetic studies calculate north-south contraction rates ranging from $30 \times 10^{-9} / \mathrm{yr}$ to $100 \times 10^{-9} / \mathrm{yr}$, each of our models scales the published rates to $85 \times 10^{-9} / \mathrm{yr}$ northsouth contraction to facilitate comparison among the proposed principal contractions. Although fault-slip rates certainly depend on rate of remote strain, the average fault-slip vector rake depends only on the relative values of remote principal strains applied to each model. The $85 \times 10^{-9} / \mathrm{yr}$ value for north-south contraction is an average of the range reported by Walls et al. (1998) and is between that calculated by Bawden et al. (2001) and Argus et al. (1999). Walls et al. (1998) report variable north-south cumulative velocities over a distance of $100 \mathrm{~km}$ ranging from $7.5 \mathrm{~mm} / \mathrm{yr}$ to 9.5 $\mathrm{mm} / \mathrm{yr}$ (Walls et al., 1998). Because remote strain is applied uniformly to our models, we average these velocities and integrate over a distance of $100 \mathrm{~km}$ to arrive at the applied $85 \times 10^{-9} / \mathrm{yr}$ north-south contraction.

Model A (Walls type) has a north-south contraction rate of $85 \times 10^{-9} / \mathrm{yr}$ and east-west extension at a rate of $60 \times$ $10^{-9} / \mathrm{yr}$ (Fig. 2 IIA). In model B, the Argus-type model, we apply uniform $85 \times 10^{-9} / \mathrm{yr}$ north-south horizontal contraction and zero east-west extension (Fig. 2 IIB). Model C uses the tectonic strain determined by Bawden et al. (2001) with principal contraction rate at $\mathrm{N} 36^{\circ} \mathrm{E}$ normalized to $85 \times$ $10^{-9} / \mathrm{yr}$ north-south contraction. This tectonic boundary condition resolves into an east-west contraction rate of $\sim 45$ $\times 10^{-9} / \mathrm{yr}$ and shear-strain rate of $\sim 60 \times 10^{-9} / \mathrm{yr}$ (Fig. 2 IIC). For model D, we apply north-south contraction rate of $85 \times 10^{-9} / \mathrm{yr}$ and $45 \times 10^{-9} / \mathrm{yr}$ east-west contraction with zero shear strain to assess the viability of east-west contraction with the north-south and east-west oriented principal strain axes used in models A and B (Fig. 2 IID).

\section{Fault Surfaces and Host Rock Properties}

Surfaces representing the Los Angeles basin faults utilized in this study are modified products of the Southern California Earthquake Center (SCEC) Community Fault Model (CFM) working group (Plesch and Shaw, 2000; http://structure.harvard.edu/cfma/). Fault surfaces are composed of triangular elements, the vertices of which are prescribed by CFM workers. CFM vertex spacing varies according to resolution of the data available for each fault surface. To increase numerical stability of the models, we have coarsened some fault meshes to maintain relatively uniform triangular element size; however, coarsening does not sacrifice the resolved nonplanarity of geologic fault surfaces (Fig. 1).

One potential source of underestimation for average slip rate is the inclusion of lateral tips on faults that extend beyond the boundaries of our study area. Elements near the lateral tips of these faults will have artificially lower slip rates than expected and thereby lower the average modeled slip rate. To reduce this effect, the Newport-Inglewood, Whittier, and Palos Verdes faults are extended beyond the boundaries of the study area.

Because fault surfaces are defined within the upper 17 $\mathrm{km}$ of the crust, slip rates will also approach zero at the lower tips of modeled faults at depth. The CFM workers have extended each of the faults to the local base of seismicity. Below 15-17 km, we expect faults to transition from planes of discrete slip to zones of distributed shear strain (e.g., Scholz, 2002). Thus, the modeled fault tips at these depths may limit the average reverse- and strike-slip rates on many large faults. This effect may be offset by the assumption that the faults are freely slipping within the upper $17 \mathrm{~km}$ of the models. Natural fault surfaces are expected to have some resistance to sliding so that the freely slipping faults within the model may overestimate slip rates. However, both of these limitations affect all faults equally and do not alter the slip-vector rakes, so that the modeled slip results can be used for validating the tectonic boundary conditions.

The heterogeneous composition of the Los Angeles basin includes an upper 3 to $5 \mathrm{~km}$ of sedimentary strata underlain by more competent basement composed of sandstones, igneous, and metamorphic rocks. Within the BEM models, we prescribe a uniform Poisson's ratio of 0.25 and Young's modulus of $30 \mathrm{GPa}$ to approximate the average properties of sandstone and gneissic bedrock underlying the Los Angeles basin (Birch, 1966). The difference in rheology 


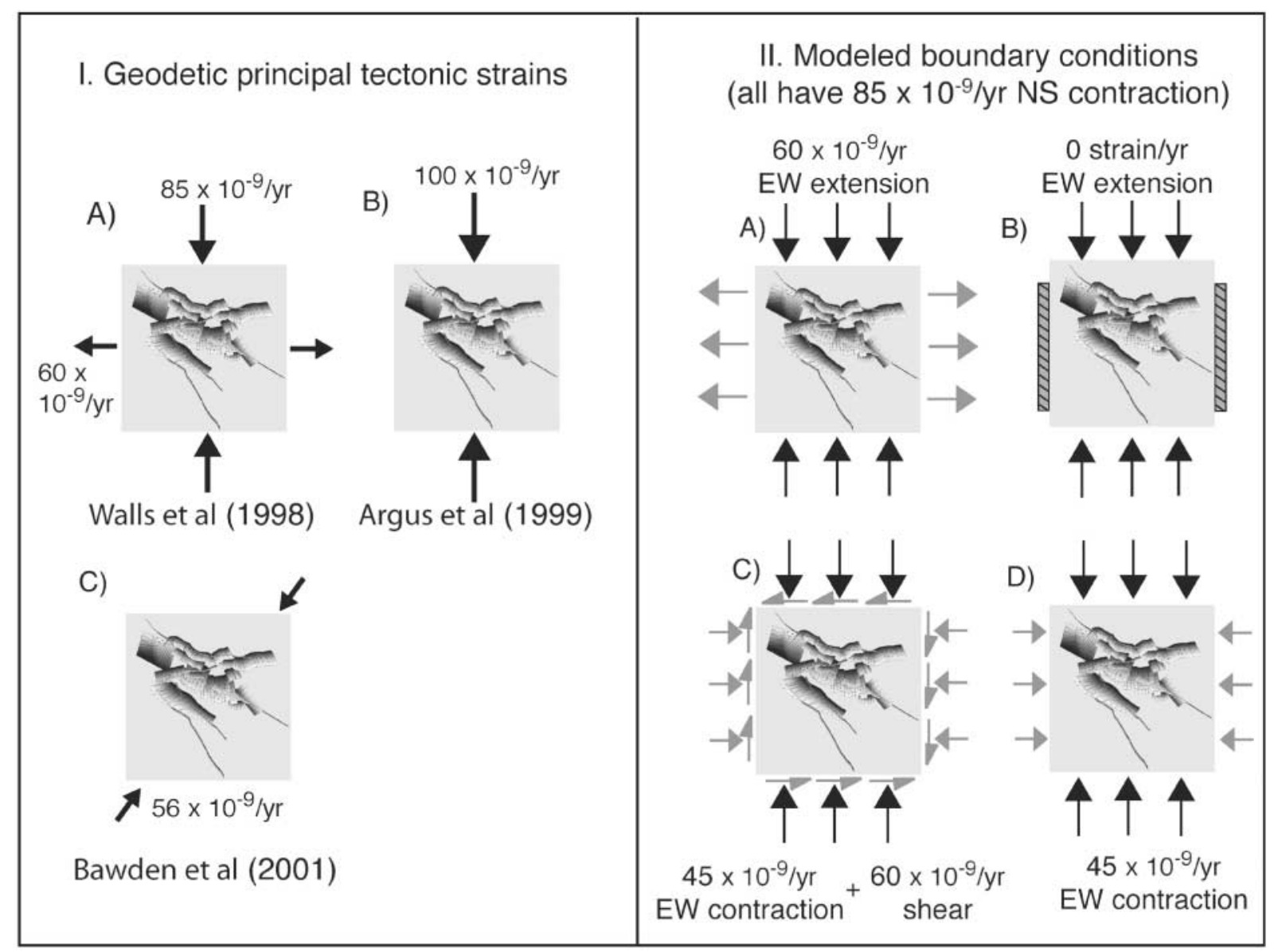

Figure 2. (I) Illustration of published geodetic principal tectonic strain rates (arrows) for the Los Angeles basin. (a) 85 nanostrain/yr north-south contraction with 60 nanostrain/yr east-west extension (Walls et al., 1998). (b) $\sim 100$ nanostrain/yr northsouth contraction estimated from Argus et al. (1999). (c) 56 nanostrain/yr contraction at $\mathrm{N} 36^{\circ} \mathrm{E}$ (Bawden et al., 2001). (II) Representations of modeled tectonic boundary conditions. For comparison purposes, all models have 85 nanostrain/yr north-south contraction (black arrows). The gray arrows highlight the differences between the models, which are intended to simulate various geodetically derived principal strains for the Los Angeles basin (I). (a) Model A is the Walls-type model, with north-south contraction and 60 nanostrain/yr east-west extension. (b) Model B is the Argus-type vertical thickening model with north-south contraction and no east-west extension. (c) Model C is the Bawden-type model with north-south contraction, 45 nanostrain/yr east-west contraction, and 60 nanostrain/yr shear strain. (d) Model D facilitates comparison of east-west contraction with models A and B by applying north-south contraction, 45 nanostrain/yr east-west contraction, and zero shear strain.

with depth could influence slip distribution but is not expected to alter the direction of slip on the faults.

The period simulated in the models should both exceed the characteristic earthquake cycle for all faults in the models and should span a period sufficiently short to permit quasistatic analysis. To encompass a reasonable earthquake recurrence interval for the Los Angeles basin faults (Ward and Valensise, 1994; Dolan et al., 1995; McNeilan et al., 1996; Grant et al., 1997; Dolan et al., 2000a; Oskin et al., 2000; Dolan et al., 2003), and to ensure infinitesimal strain, we simulate 5000 years of deformation. This time span bridges the gap between geodetically inferred active slip rates
( $\leq 10$ years) and geologically determined late-Quaternary $(\leq 10,000$ years $)$ slip rates.

\section{Slip Rates and Fault Slip Vector Rake Results}

To assess the mechanical viability of the proposed tectonic boundary conditions, the modeled fault-slip rates are compared with geologically determined late-Quaternary rates discussed earlier in Slip Rates on Faults of the Los Angeles Basin (Fig. 3). Because reverse- and strike-slip rates are commonly difficult to establish, we also compare the modeled style of faulting as indicated by the rake of the 
(a)

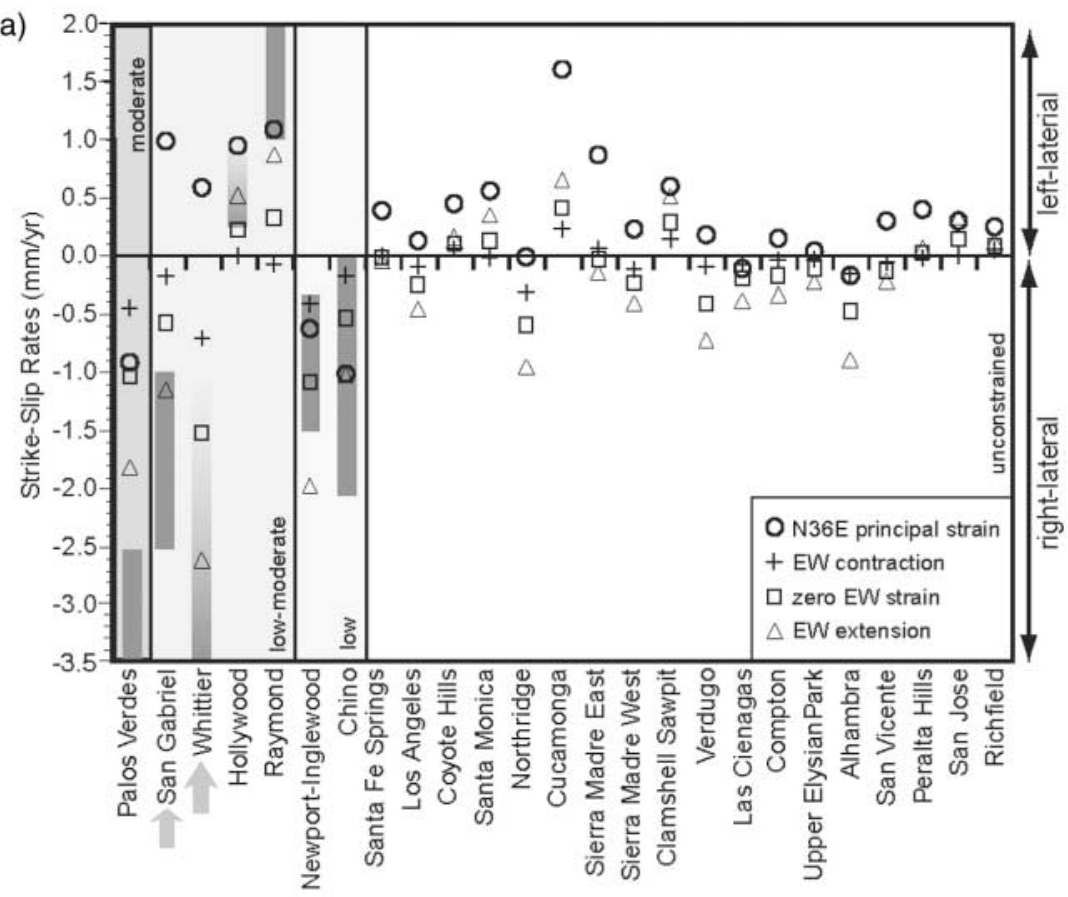

(b)

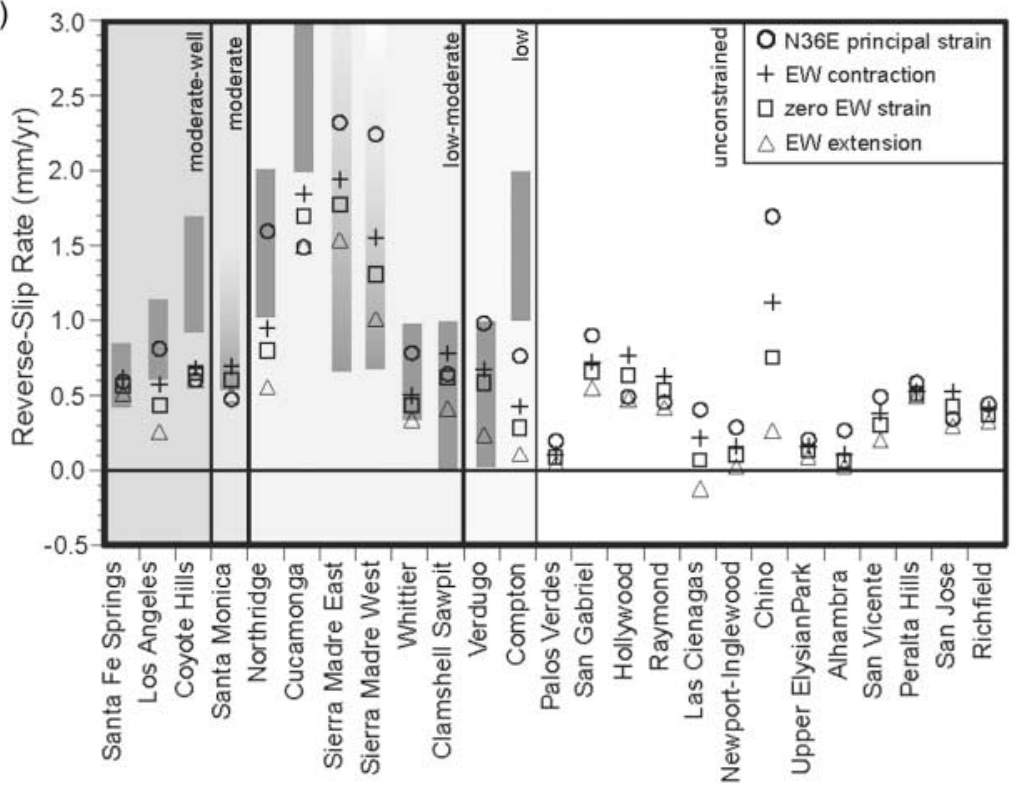

Figure 3. Modeled strike-slip rates (a) and reverse-slip rates (b) on Los Angeles basin faults compared with published geologic rates. Model rates are shown for the Walls-type east-west extension model (triangles), Argustype vertical thickening model (squares), the Bawden-type east-west contraction models with shear (circles), and the modified Bawden model without shear (crosses). Ranges of geologic slip rates are represented by vertical gray bars. Faults are listed in order of reliability of geologic observations, with the highest reliability group to the left. Note that the order is different for strike- and dip-slip rates. Negative strike-slip rates are right-lateral, whereas positive strike-slip rates are right-lateral. Large arrows indicate faults for which the Bawden-type model produces opposite slip sense from the geologic observations. The upper range for dipslip rate on the Cucamonga fault is $5 \mathrm{~mm} / \mathrm{yr}$. average net slip vector to geologic observations of fault-slip style. Although, in general, the style of faulting is more easily constrained from geologic observations than slip rate, some faults exhibit a range of faulting styles. For example, reverse- to strike-slip ratios for the Whittier fault range from $\sim 0.08$ (Gath et al., 1992) to 0.4 (Bjorklund and Burke, 2002), yielding rakes of $\sim 175^{\circ}$ and $158^{\circ}$, respectively (where pure right-lateral slip $=0^{\circ}$, pure reverse slip $=90^{\circ}$, and pure left-lateral slip $=180^{\circ}$; see legend for Fig. 4). Nonetheless, faults with primarily reverse slip (i.e., the Puente Hills blind-thrust system and Sierra Madre faults) are easily distinguishable from primarily strike-slip faults (i.e., Newport-Inglewood and Alhambra Wash faults).
Discrepancies between the modeled and geologic slip rates and slip-vector rakes may arise from either inaccurate tectonic boundary conditions or inaccurate fault geometry. To assess the most mechanically viable tectonic boundary conditions we evaluate the overall match of slip vector rake for all faults. The tectonic boundary conditions that produce the best fit to geologically observed slip-vector rakes are considered to be the most viable conditions for the Los Angeles basin. Faults with significant slip rate or style mismatch regardless of tectonic boundary conditions may have geometric errors and are discussed in Discrepancies Between Modeled and Geologic Slip Rates. 


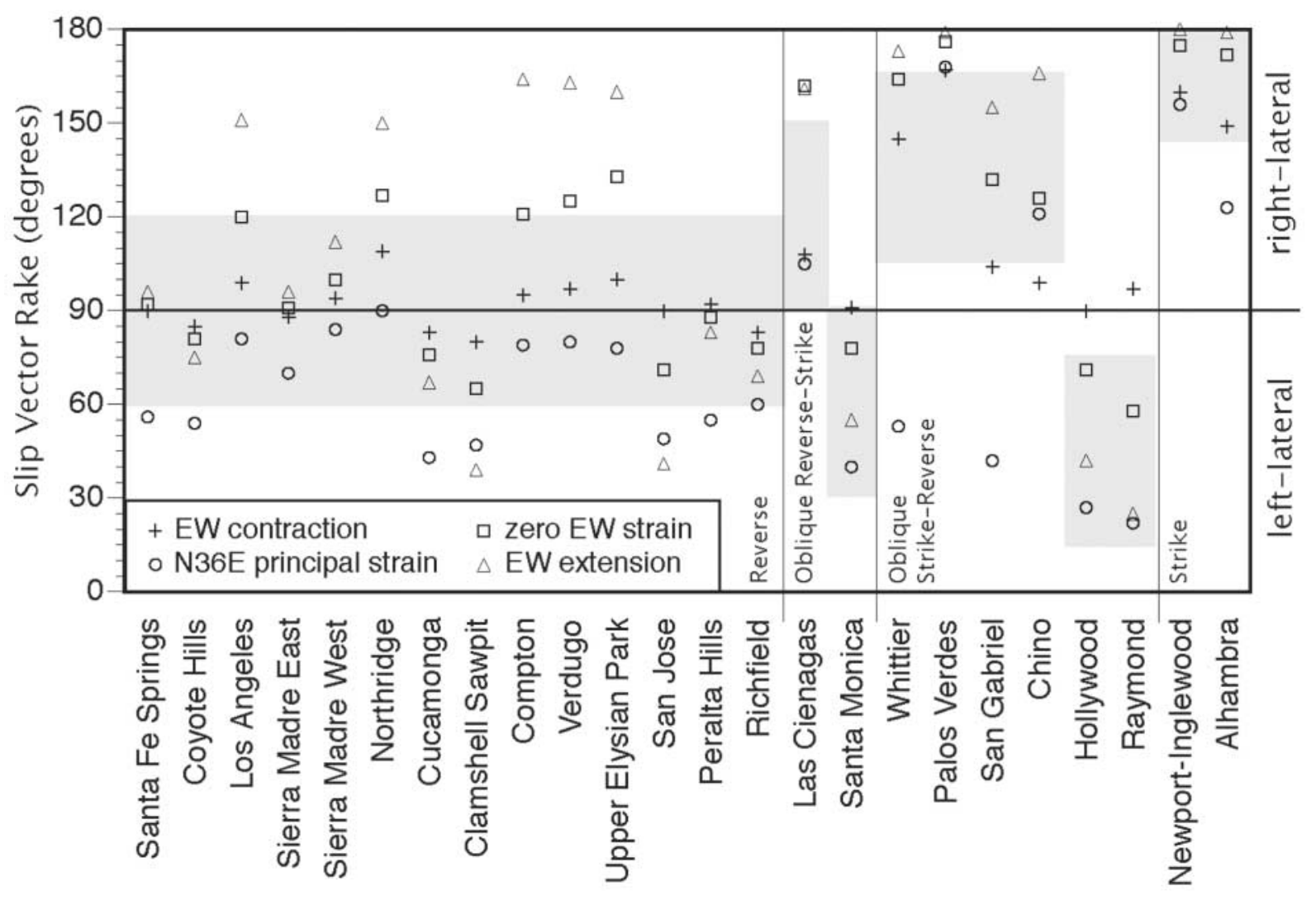

Figure 4. The average fault-slip vector rake is calculated from magnitudes and directions of dip- and strike-slip components. We use a right-hand convention, where slip rake is measured from $0^{\circ}$ for pure right-lateral strike-slip faulting to $180^{\circ}$ for pure left-lateral strike slip faulting. Pure reverse-slip faults have a slip vector of $90^{\circ}$. In comparing reverse- to strike-slip ratios among the models, the faults are grouped according to their geologically observed slip vector rake, with primarily reverse-slip faults on the left. Triangles represent the Walls-type model with $60 \times 10^{-9} / \mathrm{yr}$ east-west extension; squares represent the Argus-type vertical thickening model with zero eastwest extension; circles represent the Bawden-type model with $45 \times 10^{-9} / \mathrm{yr}$ east-west contraction and $60 \times 10^{-9} / \mathrm{yr}$ shear strain; crosses represent the modified Bawdentype vertical thickening model with $45 \times 10^{-9} / \mathrm{yr}$ east-west contraction and zero shear strain. The shaded boxes represent the accepted range for each group of faults.

\section{Slip Rate Comparison}

Although slip style provides a more robust test of tectonic boundary condition viability than slip rates, we present the model slip rates (1) to build our insight into the sensitivity of slip rates to tectonic boundary conditions, (2) to examine any major discrepancies between the model and geologic slip rates, and (3) to explore potential seismic hazards on faults for which slip rates are currently poorly constrained (discussed in Implications for Seismic Hazard on Faults with Poorly Constrained Slip Rates).

Strike-slip faulting along the many northeast-southwest trending faults of the Los Angeles basin is expected to be promoted by escape tectonics (models undergoing east-west extension). Accordingly, the models with faster east-west extension systematically produce faster strike-slip on all faults (Fig. 3). The modified Bawden-type model, with 45 $\times 10^{-9} / \mathrm{yr}$ east-west principal contraction, produces the slowest strike slip. Although the Bawden-type model has equally slow east-west extension and might also be expected to produce slow strike-slip rates, the pure shear resolved from the oblique $\mathrm{N} 36^{\circ} \mathrm{E}$ contraction promotes strike slip.

All modeled faults slip with reverse sense of dip slip, except for the Las Cienegas fault under east-west extension, which has a small $(0.13 \mathrm{~mm} / \mathrm{yr})$ normal slip rate. The location of this fault near several larger faults accommodating faster reverse slip (e.g., the Los Angeles fault) as well as the northwest-southeast trend of the Las Cienegas fault encourage slight normal slip under east-west extension. Increasing east-west contraction rates consistently produces faster reverse slip along most faults. Reverse-slip rate differences between the Bawden-type model and the modified Bawdentype model, with east-west and north-south oriented principal strain components, highlight the influence of oblique principal contraction. Under Bawden-type boundary condi- 
tions, with principal contraction oriented at $\mathrm{N} 36^{\circ} \mathrm{E}$, many faults striking northwest-southeast (e.g., Whittier and Newport-Inglewood) show faster reverse-slip rates and faults striking northeast-southwest (e.g., Santa Monica and Raymond) have slower reverse-slip rates than the modified Bawden-type model, with principal strains parallel to the cardinal directions (Fig. 3).

With a few notable exceptions, all models produce slip sense consistent with geologic observations. The Whittier and San Gabriel faults, each documented as having rightlateral strike geologic separation, slip left-laterally under modeled Bawden-type boundary conditions. Left-lateral slip does not result from the modified Bawden-type model, indicating that this slip sense reversal is a consequence of oblique principal contraction at $\mathrm{N} 36^{\circ} \mathrm{E}$ rather than east-west contraction. These results call into question the applicability of the Bawden-type $\mathrm{N} 36^{\circ} \mathrm{E}$ contraction direction in at least parts of the Los Angeles basin.

\section{Rake of Fault-Slip Vectors}

Paleoseismic slip rates collected at sites along the surface traces of faults may reflect slip rates that are faster or slower than the average of the entire subsurface fault surface (Griffith and Cooke, 2004). Because we calculate average slip rate over the entire modeled fault surface, a close fit to geologic rates is less important than matching the rake of the average slip vector of individual faults. Furthermore, for reasons presented at the start of this section, slip-vector rake provides a more robust assessment of the viability of various tectonic boundary conditions. We calculate the model-generated net slip-vector rake as a simple function of the relative magnitude and direction of the average dip- and strike-slip components. The Las Cienegas fault under eastwest extension is the only fault with normal sense of dip slip and the slip-rake plots greater than $180^{\circ}$ (Fig. 4). The grey boxes in Figure 4 show $60^{\circ}$ ranges of expected slip vector rakes for each of the faults based on geologic information (e.g., Table 1).

For the models with north-south oriented principal contraction (models A, B and D; Fig. 2), all faults have increasing reverse slip (steeper slip vector; Fig. 4) with slower eastwest extension. Thus, vertical thickening promotes reverse slip and inhibits strike slip. The Bawden-type boundary condition, with $\mathrm{N} 36^{\circ} \mathrm{E}$ principal contraction and significant east-west contraction, produces slip vector rakes with larger reverse-slip components on most but not all the faults. This inconsistency in the pattern of fault-slip rakes is due to the horizontal shear strain resolved from oblique contraction on this model.

For the 14 faults that display geologic evidence for primarily reverse-slip-vector rakes, the modified Bawden-type model, with east-east contraction, produces fault-slip-vector rakes the most consistent with geologic observations. Both the Argus- and Bawden-type models produce reversedominant slip-vector rakes (within $45^{\circ}$ of pure dip slip) on all primarily reverse-slip faults (Fig. 4). In contrast, Wallstype boundary conditions, with east-west extension, produce slip-vector rakes well outside of the expected range for seven of the 14 primarily reverse faults (Fig. 4). For the two primarily strike-slip faults, all remote strain conditions except contraction at $\mathrm{N} 36^{\circ} \mathrm{E}$ produce slip patterns consistent with geologic observations. For the six faults that display geologic evidence for oblique strike-reverse slip, the Walls-, Argus-, and modified Bawden-type models are equally consistent with geologic slip-vector rakes though the modified Bawden-type model overestimates reverse slip and the Argus- and Wall-type models overestimate right-lateral strike slip. As mentioned previously, the Bawden-type model produces strike slip on the Whittier and San Gabriel faults with opposite sense to geologic observations.

Slip-style misfit was quantified for each fault by calculating the total deviation in degrees of the modeled slip vector rake from the expected range of rakes (shaded regions on Fig. 4). For example, the Bawden-type model has a misfit of $5^{\circ}$ for the Santa Fe Springs fault because the modeled slip falls $5^{\circ}$ outside the shaded region on the slip-vector-rake plot. Misfit for all faults was then summed to indicate overall mismatch for each tectonic boundary condition modeled (Fig. 5). The Walls-type model with east-west extension has the largest misfit, almost exclusively because of underestimation of reverse-slip rates on oblique and reverse-slip faults. Misfit for the Bawden-type oblique contraction model stems primarily from underestimating strike slip on strikeslip and strike-oblique slip faults. The Argus-type and modified Bawden-type models, with zero and moderate eastwest contraction, have the best overall match of average slip vector rake. The Argus-type model overestimates strike slip on reverse and oblique faults, whereas the modified Bawdentype model overestimates reverse slip on strike-slip faults. These results suggest that boundary conditions between these two types would have the lowest misfit to the expected range of slip vectors. Thus, we expect that north-south contraction accompanied by slow east-west contraction, which induces vertical thickening of the Los Angeles basin, is a more suitable tectonic boundary condition for the Los Angeles basin than escape tectonics with east-west extension or oblique principal contraction.

\section{Discrepancies between Modeled and Geologic Slip Rates}

Except for the Bawden-type model (N36 ${ }^{\circ}$ contraction), which produces unexpected left-lateral slip along some faults, all the tectonic boundary conditions modeled produce reverse- and strike-slip rates with reasonable fit to inferred/ paleoseismic ranges for faults with low to well-constrained slip rates and fault-surface topologies. Under north-south and east-west principal strains, the modeled strike-slip rates are generally lower than or within the range of many of the geologic rates. Slow slip rates may indicate inaccurate fault geometry and either increasing the length of faults or the 


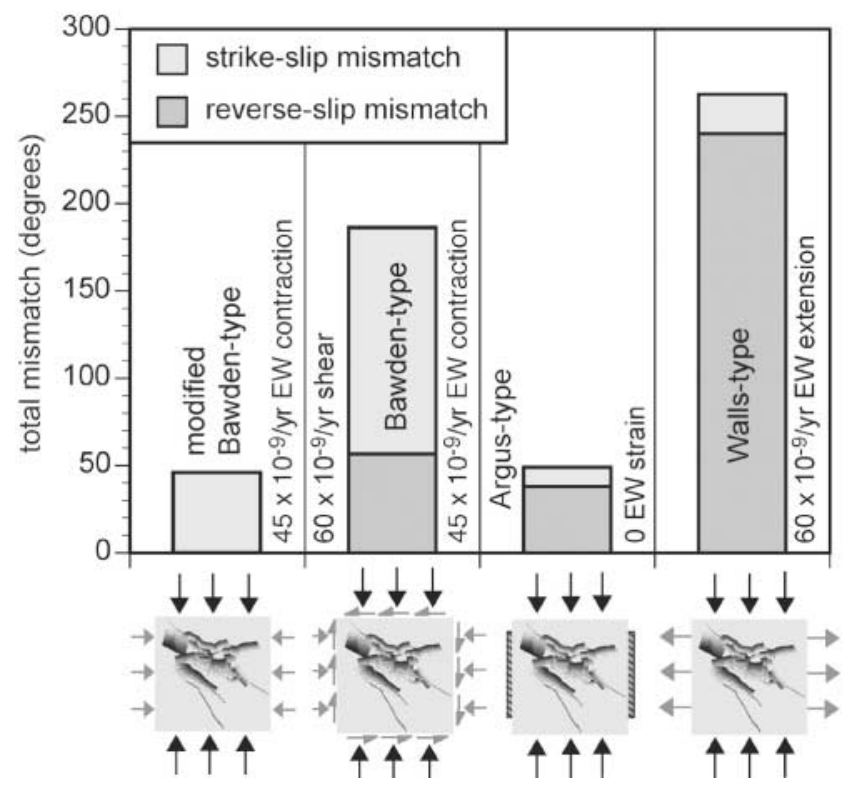

Figure 5. Total misfit, for each tectonic boundary condition, of modeled fault-slip-vector rake to expected slip-vector rake based on geologic observations. Only faults with slip-vector rake outside of the expected range (shaded boxes in Fig. 4) contribute to total misfit. Individual fault misfit is calculated as the discrepancy between slip-vector rake to the acceptable range. The Walls-type model, with east-west extension, produces generally excessive strike-slip, whereas the modified Bawden-type, with east-west contraction, produces excessive reverse-slip along strike-slip faults. The modified Bawden-type matches well the range of slip-vector orientations on reverse faults and incurs no reverse-slip mismatch. The tectonic boundary conditions with negligible or slow east-west contraction produce the best fit of modeled to geologic fault-slip-vector rake.

interconnectivity of individual faults could increase the strike-slip rate. For example, the Alhambra Wash fault, a northern splay of the Whittier fault, might have a faster strike-slip rate if linked to the Whittier fault to the south (Fig. 1). Alternatively, the slip-rate discrepancies may arise because present-day slip rates are not the same as the observed long-term slip rates. For example, postseismic relaxation may account for discrepancies between present-day and geologic slip rates (e.g., Dixon et al., 2000). Alternatively, long-term slip rates may vary throughout time; the Holocene slip rate for the San Gabriel fault is thought to be slower than the long-term rate (Dolan et al., 2001).

Many of the modeled reverse-slip rates lie within inferred/paleoseiemic ranges; modeled reverse-slip rates on the Coyote Hills, Cucamonga, and Compton faults are slower than the paleoseismic/inferred ranges (Fig. 2b). None of the models overpredict reverse-slip rates on the faults for which geologic rates are available. One source of reverseslip mismatch common to several faults is the effect of basal fault tips, which artificially lower the average reverse-slip rates on crustal scale faults that extend below the brittle crust. For example, the modeled Cucamonga fault extends only to $13.5 \mathrm{~km}$ depth (along dip length of $\sim 20 \mathrm{~km}$ ) with an average reverse-slip rate of $\sim 1.70 \mathrm{~mm} / \mathrm{yr}$. Increasing the depth of the Cucamonga fault by increasing its along-dip length would increase the average reverse-slip rate of this fault in the model. Because displacement scales directly with fault length for elastic cracks (e.g., Pollard and Segall, 1987) extending the down-dip length of the Cucamonga fault to $\sim 24 \mathrm{~km}$ and a depth of $\sim 16.5 \mathrm{~km}$ would produce an average slip rate that matches the geologic slip rate. This depth difference of only $3 \mathrm{~km}$ demonstrates the sensitivity of our modeled slip rates fault size; therefore, most underestimations of reverse-slip rate by the models (e.g., Coyote Hills and Compton) might be explained by underestimations of fault depth. The inferred rate on the Compton fault is poorly constrained as is its geometry; therefore, underestimation of this slip rate may not be problematic. Inferred slip rates on the Coyote Hills and Los Angeles faults are both calculated assuming the onset of fault activity for both faults was 1.6 m.y.a. (Shaw et al., 2002). Because the PHT blind-thrust system may have evolved from east to west, the inferred rate on the Los Angeles fault may be underestimated (J. Shaw, personal comm., 2003), which would increase the discrepancy between model and geologic slip rates unless the fault surfaces were extended to deeper depths.

Modeled slip rates may also differ from geologic rates because of heterogeneities and other features not explicitly included within our models. For example, under equal tectonic strain, faults within sedimentary layers slip less than faults within relatively stiff basement rock because a greater portion of the tectonic strain is accommodated by compliance of the soft rock surrounding the fault. This effect would influence the outcome of our study if some faults are limited to the sedimentary basins and others are limited to the underlying bedrock. However, because all of the simulated faults cross-cut both basin sediments and stiff bedrock, a homogeneous approximation can sufficiently estimate the effects of remote loading conditions on fault-slip rates. Another factor that may cause local variations in slip rate results is the high topography of the San Gabriel Mountains north of the Sierra Madre fault, topography not considered in our half-space models. Because the influence of topography extends to approximately the height of the topography, topographic effects are localized near topographic gradients (McTigue and Mei, 1981). The San Gabriel Mountains should only influence stresses along the upper portion of the Sierra Madre fault. Furthermore, we expect that effects of topographic gradients on overall modeled average slip rates is much smaller than the effect of differing tectonic boundary conditions.

\section{Implications for Seismic Hazard on Faults with Poorly Constrained Slip Rates}

The slip rates on many faults remain relatively poorly constrained with unclear potential for seismic activity. Hav- 
ing determined the most mechanically viable tectonic boundary condition we can investigate the slip potential of these unconstrained faults. Under preferred boundary conditions (north-south contraction with slow-to-moderate east-west contraction) several poorly constrained faults exhibit high $(>0.5 \mathrm{~mm} / \mathrm{yr})$ strike- and reverse-slip rates. Poorly constrained faults with high strike-slip rates include the Newport-Inglewood, Chino, Northridge, Verdugo, and Alhambra faults. Similarly, fast reverse-slip rates occur on the Verdugo, Chino, San Gabriel Hollywood, Raymond, and Peralta Hills faults (Fig. 4). The relatively fast slip rates on these modeled faults suggest that the associated seismic hazards may be currently underestimated. More work should be done to constrain the slip rate and subsurface geometry of these faults. Furthermore, the modeled faults that exhibit fast slip rates are important for paleoseismic investigation because their poorly constrained slip rates might explain part of the deficit between geologic slip rates and geodetic surface velocities (Walls et al., 1998).

Three-dimensional mechanical models provide estimates for probable strike-slip rates for buried faults or faults for which strike-slip evidence is elusive. Under north-south contraction and slow east-west extension (i.e., rates would be between Argus-type and modified Bawden-type results), some primarily reverse-slip faults, including the Los Angeles, Compton, Verdugo, Upper Elysian Park, and ClamshellSawpit faults, have significant strike-slip components (Figs. $2 \mathrm{a}$ and 4). The Verdugo and Clamshell-Sawpit faults are within regions undergoing rapid uplift (Meigs et al., 2003), indicating that crustal thickening in that region may be occurring on obliquely slipping faults. Furthermore, the suggestion of significant strike-slip along primarily reverse-slip faults indicates that assumptions of one dominant direction of slip distributed over the entire fault may oversimplify slip distribution and average rake of slip vectors on faults. Threedimensional slip distributions on faults and fault morphology must be better determined to infer slip rates from geodetic data.

\section{Conclusion}

The expression of north-south contractional strain accommodation across the Los Angeles basin has been debated since the proposal of the escape tectonics (Walls et al., 1998) and vertical thickening (Argus et al., 1999) models. The recent analysis of groundwater effects on surface motion (Bawden et al., 2001) has added fuel to this discussion. This study has evaluated four proposed tectonic boundary conditions by comparing slip style along modeled faults to geologic observations. Results suggest that north-south contraction is accommodated primarily by vertical thickening of the crust with slow east-west extensional strain.

Sensitivity studies of slip style as indicated by the average rake of slip vectors on faults in the Los Angeles basin lead us to conclude that the vertical thickening with northsouth contraction and slow east-west contraction is the most mechanically viable tectonic boundary condition because (1) Bawden-type strain conditions with $\mathrm{N} 36^{\circ} \mathrm{E}$ contraction produce conflicting sense of strike slip on the Whittier and San Gabriel faults, and (2) models with significant east-west extension (the Walls-type escape tectonics model) produce large overall misfit of modeled to geologic fault-slip-vector rake. Because Argus-type model with north-south contraction and zero east-west strain has opposite sense of mismatch as the modified Bawden-type model with north-south contraction and east-west contraction, a model with slow east-west contraction may produce slip styles very close to the geologic observations. These results suggest that, with regard to fault-slip style, north-south contraction accompanied by slow east-west strain is the most mechanically viable tectonic boundary condition for the Los Angeles basin.

\section{Acknowledgments}

The comments of two anonymous reviewers and associate editor Fred Pollitz greatly improved the manuscript. Poly3d was provided by David Pollard of Stanford University. Editing and remeshing of CFM fault surface was performed with 3DMove by Midland Valley Ltd. This research was supported by the Southern California Earthquake Center (SCEC). SCEC is funded by National Science Foundation Cooperative Agreement EAR0106924 and USGS Cooperative Agreement 02HQAG0008. This work is Southern California Earthquake Center report no. 804.

\section{References}

Argus, D. F., M. D. Heflin, A. Donnellan, F. H. Webb, D. Dong, K. J. Hurst, G. A. Jefferson, M. Lyzenga, M. Watkins, and J. F. Zumberge (1999). Shortening and thickening of metropolitan Los Angeles measured and inferred by using geodesy, Geology 27, 703-706.

Bawden, G. W., W. Thatcher, R. S. Stein, K. W. Hudnut, and G. Peltzer (2001). Tectonic contraction across Los Angeles after removal of groundwater pumping effects, Nature 412, 812-815.

Birch, A. A. (1966). Compressibility and elastic constants, in Handbook of Physical Constants, S. P. Clark (Editor), Geol. Soc. Am. Memoir, 97173.

Bjorklund, G. W., and K. Burke (2002). Four-dimensional analysis of the inversion of a half-graben to form the Whittier fold-fault systems of the Los Angeles Basin, J. Struct. Geol. 24, 1369-1397.

Clark, M. M., K. K. Harms, J. J. Lienkaemper, D. S. Harwood, K. R. Lajoie, J. A. Matti, M. J. Perkins, R. V. Rymer, R. V. Sarna-Wojcicki, R. V. Sharp, J. D. Sims, J. C. Tinsely, and J. I. Ziony (1984). Preliminary slip-rate table for late Quaternary faults of California, J. 84-106.

Cooke, M. L., and A. Kameda (2002). A two-dimensional analysis using mechanical efficiency, J. Geophys. Res. 107, no. B7, doi 10.1029/ 2001JB000542.

Crider, J. G. (1998). Fault linkage; three-dimensional mechanical interaction between echelon normalfaults, J. Geophys. Res. B, Solid Earth Planets 103, no. 10, 24,373-24,391.

Crook, R., Jr., C. R. Allen, B. Kamb, C. M. Payne, and R. J. Proctor (1987). Quaternary geology and seismic hazard of the Sierra Madre and associated faults, western San Gabriel Mountains, U.S. Geol. Surv. Profess. Pap. 1339, 27-63.

Crouch, S. L., and A. M. Starfield (1990). Boundary Element Methods in Solid Mechanics, Unwin Hyman, Boston, 322 pp.

Davis, T. L., and J. Namson (1994). A balanced cross-section of the 1994 Northridge earthquake, southern California, Nature 372, 167-169.

Davis, T. L., J. Namson, and R. F. Yerkes (1989). A cross-section of the Los Angeles area: seismically active fold and thrust belt, the 1987 
Whittier Narrows earthquake, and earthquake hazard, J. Geophys. Res. 94, no. 7, 9644-9664.

Dixon, T. H., M. Miller, F. Farina, H. Wang, and D. Johnson (2000). Present day motion of the Sierra Nevada block and some tectonic implications for the Basin and Range province, North American Cordillera, Tectonics 19, 1-24.

Dolan, J. F., and T. L. Pratt (1997). High-resolution seismic reflection profiling of the Santa Monica fault zone, West Los Angeles, California, Geophys. Res. Lett. 24, 2051-2054.

Dolan, J. F., S. A. Christofferson, and J. H. Shaw (2003). Recognition of paleoearthquakes on the Puente Hills blind thrust fault, California, Science 300, 115-118.

Dolan, J. F., E. M. Gath, L. B. Grant, M. Legg, S. Lindvall, K. Mueller, M. Oskin, D. F. Ponti, C. M. Rubin, T. K. Rockwell, J. H. Shaw, J. A. Treiman, C. Walls, and R. S. Yeats (2001). Active faults in the Los Angeles metropolitan region, SCEC Special Publication Series Southern California Earthquake Center, 1, Los Angeles.

Dolan, J. F., K. Sieh, and T. K. Rockwell (2000a). Late Quaternary activity and seismic potential of the Santa Monica fault system, Los Angeles, California, Geol. Soc. Am. Bull. 112, 1559-1581.

Dolan, J. F., K. Sieh, T. K. Rockwell, R. S. Yeats, J. H. Shaw, J. Suppe, G. Huftile, and E. M. Gath (1995). Prospects for larger or more frequent earthquakes in the Los Angeles metropolitan region, Science 267, 199-205.

Dolan, J. F., D. Stevens, and T. K. Rockwell (2000b). Paleoseismologic evidence for an early- to mid-Holocene age of the most recent surface rupture on the Hollywood fault, Los Angeles, California, Bull. Seism. Soc. Am. 90, 334-344.

Durham, D. L., and R. F. Yerkes (1964). Geology and oil resources of the eastern Puente Hills area, southern California, U.S. Geol. Surv. Profess. Pap. 420 B, 62 p.

Feigl, K. L., D. C. Agnew, Y. Bock, D. Dong, A. Donnellan, B. H. Hager, T. A. Herring, D. D. Jackson, T. H. Jordan, R. W. King, K. M. Larsen, M. H. Murray, Z. Shen, and F. H. Webb (1993). Space geodetic measurement of crustal deformation in Central and Southern California, J. Geophys. Res. 98, no. 12, 21,677-21,712.

Freeman, S. T., E. G. Heath, P. D. Guptill, and J. T. Waggoner (1992). Seismic hazard assessment, Newport Inglewood fault zone, in Engineering Geology Practice in Southern California, Vol. 4, Association of Engineering Geologists, 211-231.

Fuis, G. S., T. Ryberg, N. J. Godfrey, D. A. Okaya, and J. M. Murphy (2001). Crustal structure and tectonics from the Los Angeles Basin to the Mojave Desert, southern California, Geology, 29, no. 1, 15-18.

Fuis, G. S., R. W. Clayton, P. M. Davis, T. Ryberg, W. J. Lutter, D. A. Okaya, E. Hauksson, C. Prodehl, J. M. Murphy, M. L. Benthien, S. A. Baher, M. D. Kohler, K. Thygesen, G. Simila, and R. Keller (2003). Fault systems of the 1971 San Fernando and 1994 Northridge earthquakes, southern California: relocated aftershocks and seismic images from LARSE II, Geology, 00, no. 2, 171-174.

Gath, E. M., T. Gonzalez, and T. Rockwell (1992). Slip rate of the Whittier fault based on 3D trenching at Brea Southern California, Abstr. Programs, Geol. Soc. Am. 24, no. 5, 26.

Grant, L. B., J. T. Waggoner, T. K. Rockwell, and C. von Stein (1997). Paleoseismicity of the north branch of the Newport-Inglewood fault zone in Huntington Beach, California, from cone penetrometer test data, Bull. Seism. Soc. Am. 87, no. 2, 277-293.

Gray, C. H., Jr. (1961). Geology of the Corona South in the Santa Ana Narrows area, Riverside, Orange, and San Bernadino counties, California, and mines and mineral deposits of the Corona South quadrangle, Riverside and Orange Counties, California, Calif. Div. Mines Geol. Bull. 178, 120 p.

Griffith, W. A., and M. L. Cooke (2004). Mechanical validation of the three-dimensional intersection geometry between the Puente Hills blind-thrust system and the Whittier fault, Bull. Seism. Soc. Am. 94, 493-505.

Haukkson, E. (1987). Seismotectonics of the Newport-Inglewood fault zone in the Los Angeles Basin, southern California, Bull. Seism. Soc. Am. 77, 539-561.

Hauksson, E. (1990). Earthquakes, faulting, and stress in the Los Angeles Basin, J. Geophys. Res. 95, no. B10, 15,365-15,394.

Haukkson, E. (1994). The 1991 Sierra Madre earthquake sequence in southern California, Seismological and tectonic analysis, Bull. Seism. Soc. Am. 84, 1058-1074.

Huftile, G. J., and R. S. Yeats (1996). Deformation rates across the Placerita (Northridge $\mathrm{Mw}=6.7$ aftershock zone) and Hopper Canyon segments of the western Transverse ranges deformation belt, Bull. Seism. Soc. Am. 86, S3-S18.

Ingersoll, R. V., and P. E. Rumelhart (1999). Three-stage evolution of the Los Angeles Basin, Southern California, Geology 27, no. 7, 593-596.

Jones, L. M., K. Sieh, E. Haukkson, and L. K. Hutton (1990). The 3 December 1988 Pasadena earthquake: evidence for strike-slip motion on the Raymond fault, Bull. Seism. Soc. Am. 80, 474-482.

Kahle, J. E. (1986). The San Gabriel fault near Castaic and Saugus, Los Angeles County, California Division of Mines and Geology Fault Evaluation Report FER 178, 8 p.

Langenheim, V. E., A. Griscom, R. C. Jachens, and T. G. Hildebrand (2000). Preliminary potential-field constraints on the geometry of the San Fernando Basin, southern California, U.S. Geol. Surv. Open-File Rept. 00-0219, 36 pp.

Lindvall, S. C., T. K. Rockwell, C. Walls, and M. Bornyasz, (1995). Late Quaternary deformation of Pacoima Wash terraces in the vicinity of the 1971 San Fernando earthquake rupture, northern San Fernando Valley, California, EOS 76, F363.

Marin, M., J. F. Dolan, R. D. Hartleb, S. A. Christofferson, A. Z. Tucker, and L. A. Owen (2000). A latest Pleistocene-Holocene slip rate on the Raymond fault based on 3-D trenching, East Pasadena, California, EOS 81, no. 48 (suppl.), F855.

McGill, J. T. (1989). Geologic maps of the Pacific Palisades area, Los Angeles, California, U.S. Geol. Geol. Surv. Misc. Invest. Series Map I-1828.

McNeilan, T. W., T. K. Rockwell, and G. S. Resnick (1996). Style and rate of Holocene slip, Palos Verdes Fault, southern California, J. Geophys. Res. 101, 8317-8334.

McTigue, D. F., and C. C. Mei (1981). Gravity-induced stresses near topography of small slope, J. Geophys. Res. 86, 9268-9278.

Meigs, A., N. Brozovic, and M. L. Johnson (1999). Steady, balanced rates of uplift and erosion of the Santa Monica Mountains, California, $\mathrm{Ba}$ sin Res. 11, 59-73.

Nardin, T. R., and T. L. Henyey (1978). Pliocene-Pleistocene diastrophismof the Santa Monica and San Pedro shelves, California Continental Borderland, AAPG Bull. 62, 247-272.

Nicholson, C., C. C. Sorlien, T. Atwater, J. C. Crowell, and B. P. Luyendyk (1994). Microplate capture, rotation of the western Transverse Ranges, and initiation of the San Andreas transform as a low-angle fault system, Geology 22, 491-495.

Oskin, M., K. Sieh, T. K. Rockwell, G. Miller, P. Guptill, M. Curtis, S. McArdle, and P. Elliot (2000). Active parasitic folds on the Elysian Park anticline; implications for seismic hazard in central Los Angeles, California, Geol. Soc. Am. Bull. 112, no. 5, 693-707.

Peterson, M. D., and S. G. Wesnousky (1994). Fault slip rates and earthquake histories for active faults in Southern California, Bull. Seism. Soc. Am. 84, no. 5, 1608-1649.

Plesch, A., and J. H. Shaw (2000). 3-D modeling of active thrust faults in the Los Angeles Basin, CA, EOS Trans. AGU 81, no. 48, 854.

Pollard, D. D., and P. Segall (1987). Theoretical displacement and stresses near fractures in rock: with applications to faults, joints, veins, dikes, and solution surfaces, in Fracture Mechanics of Rock, B. K. Atkinson (Editor), Academic Press, London, 277-349.

Ponti, D. J., J. P. Quinn, J. W. Hillhouse, and C. L. Powell, II (1996). Quaternary chronostratigraphic constraints on deformation and blindthrust faulting, northern Los Angeles Basin, California, EOS Trans. $A G U$ E644.

Quinn, J. P., D. J. Ponti, J. W. Hillhouse, C. L. Powell, II, K. McDougall, 
A. M. Sarna-Wojcicki, J. A. Barron, and R. J. Felck (2000) Quaternary constraints on deformation and blind-thrust faulting, northern Los Angeles Basin, Final Tecnical report, Journal 1434-HQ-9800025, $22 \mathrm{pp}$.

Rockwell, T. K., E. M. Gath, and T. Gonzalez (1992). Sense and rate of slip on the Whittier fault zone, eastern Los Angeles Basin, California, M. L. Stout (Editor), Proc. 35th Annual Meeting, Association of Engineering Geologists, 2-9 October, Association of Engineering Geologists, Santa Ana, California.

Rubin, C. M., S. C. Lindvall, and T. K. Rockwell (1998). Evidence for large earthquakes in metropolitan Los Angeles, Science 281, 398402.

Savage, H. (2003). Three dimensional interaction among fault-cored folds, Master's Thesis, University of Massachusetts, Amherst, Massachusetts, 108 pp.

Savage, H. M., and M. L. Cooke (2003). Can flat-ramp-flat fault geometry be inferred from fold shape? A comparison of kinematic and mechanical folds, J. Struct. Geol. 25, 2023-2034.

Schneider, C. L., C. Hummon, R. S. Yeats, and G. L. Huftile (1996). Structural evolution of the northern Los Angeles basin, California, based on growth strata, Tectonics 15, no. 2, 341-355.

Schoellhammer, J. E., J. G. Vedder, R. F. Yerkes, and D. M. Kinney (1981). Geology of the northern Santa Ana Mountains U.S. Geol. Surv. Profess. Pap. 420-D, 109 p.

Scholz, C. H. (2002). The Mechanics of Earthquakes and Faulting, Cambridge University Press, New York, $471 \mathrm{pp}$.

Shaw, J. H., and J. Suppe (1996). Earthquake hazards of active blind-thrust faults under the central Los Angeles basin, California, J. Geophys. Res. 101, 8623-8642.

Shaw, J. H., and P. M. Shearer (1999). An elusive blind thrust beneath metropolitan Los Angeles, Science 283, 1516-1518.

Shaw, J. H., A. Plesch, J. Dolan, T. Pratt, and P. Fiore (2002). Puente Hills blind-thrust system, Los Angeles, California, Bull. Seism. Soc. Am. 92, no. 8, 2946-2960.

Sibson, R. H. (1982). Fault zone models, heat flow, and the depth distribution of earthquakes in the continental crust of the United States, Bull. Seism. Soc. Am. 72, no. 1, 151-163.

Thomas, A. L. (1993). Poly3D: a three dimensional, polygonal element, displacement disconitinuity boundary element computer program with applications to fractures, faults, and cavities in the earth's crust, Master's Thesis, Stanford University, Stanford, California, 52 pp.

Tsutsumi, H., and R. S. Yeats (1999). Tectonic setting of the 1971 Sylmar and 1994 Northridge earthquakes in the San Fernando Valley, California, Bull. Seism. Soc. Am. 89, 1232-1249.

Tsutsumi, H., R. S. Yeats, and G. J. Huftile (2001). Late Cenozoic tectonics of the northern Los Angeles fault system, California, Geol. Soc. Am. Bull., 113, no. 4, 454-468.

Tucker, A. Z., and J. F. Dolan (2001). Paleoseismologic evidence for a $>8$ ka age of the most recent surface rupture on the eastern Sierra Madre fault, northern Los Angeles metropolitan region, California, Bull. Seism. Soc. Am. 91, 232-249.

Walls, C., T. Rockwell, K. Mueller, Y. Bock, S. Williams, J. Pfanner, J. Dolan, and P. Fang (1998). Escape tectonics in the Los Angeles metropolitan region and implications for seismic risk, Nature 364, 356360.

Ward, S. N., and G. Valensise (1994). The Palos Verdes Terraces, California: Bathtub rings from a buried reverse fault, J. Geophys. Res. 99, 4485-4494.

Wright, T. L. (1991). Structural geology and evolution of the Los Angeles basin, California, in Active Margin Basins, K. T. Biddle (Editor), American Association Petroleum Geologists Memoir, Tulsa, Oklahoma, 35-134.

Yeats, R. S., and G. L. Huftile (1994). Late Cenozoic tectonics of the east Ventura basin, Transverse Ranges, California, AAPG Bull. 78, 1040 1074.

Department of Geosciences

University of Massachusetts

Amherst, Massachusetts 01003

(W.A.G.)

Department of Geosciences

University of Massachusetts

Amherst, Massachusetts 01003

cooke@geo.umass.edu

(M.L.C.)

Manuscript received 28 April 2004. 